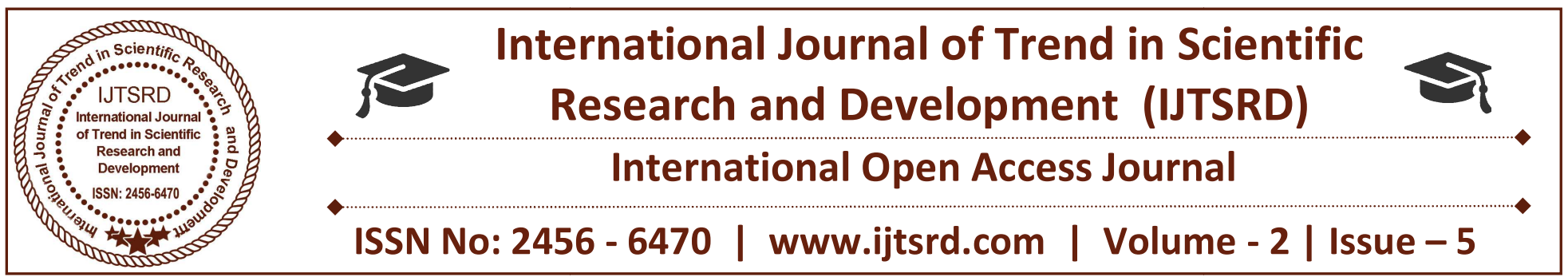

\title{
Raising Awareness Needed for Protect the Women Rights in India
}

\author{
Soumen Jana \\ Vidyasagar University, West Bengal, India
}

\begin{abstract}
India contains a huge amount of population. Among the huge population more than 586.47 million $(48.5 \%)$ are women in India as per census 2011 . In urban women population share $48.1 \%$ and rural women population share $48.6 \%$ comprising the total population of India. The rights of the women not provided properly. These are the biggest problem in India. They are deprived of their right. These problems makes India lag behind. For our country's development more awareness should be provided to the Indians people. Awareness should be provided to the women that they can enjoy their rights as well as womanhood.
\end{abstract}

The motive of my research is that a women right is being mostly violated in a large periphery. Mainly the rights of education, child marriage especially female whose are below 18years is still forcible in many places in India. By law it is strictly prohibited, but still prevailing. So in the society much awareness needed in order to protect the women rights and they are the future of our society and no one have right to seize it from them.

I adopt the doctrine research methodology. The data and information will be provided from relevant source.

This research will be helpful to me to give me some suggestion and some solution regarding the problem.

\section{INTRODUCTION}

Women are main group of inhabitant in India. They are future of the present society. We should have to protect them in every special and probable measure to build the future of strong nation. In constitution certain rights provided the children and women in order to give them equal status in the society. But this right is not provided to them properly.

The female under 14 years are not allowed to work in hazardous place as per Article 24 of the constitution. Below 18 female are not allowed to marriage, child marriage prohibition Act, 2006 is constitute. But what is the scenario of our society? In the bricks field many girls working, in many hotel girls are working, in many places they are treated very badly. They are force to work because they have to maintain their family. Even education is compulsory but especially women are not allowed for education. Society not gives them freedom. Work place inequalities is there, violation is there, discrimination is there. Here by our society lag behind. Awareness also required provides them proper guidance about rights. Awareness is highly required for provide better womanhood. If awareness is reach the woman and society no one can seize their rights. Only way to protect the rights is awareness and empowerment. This is women is beautiful gift for our society and country.

\section{PRIVILEGES OF CONSTITUTION TO}

\section{PROTECT WOMEN RIGHTS}

There are many privileges provided for protect the right of women. In the constitution part III provide fundamental rights. Article 14 provided equality before law for women. Article 15(i) stated that not to discriminate against any citizen on grounds only of religion, race, caste, sex, place of birth or any of them. Article 15(3) The State to make any special provision in favour of women and children. Article 16 stated that Equality of opportunity for all citizens in matters relating to employment or appointment to any office under the State. The State to direct its policy towards securing for men and women equally the right to an adequate means of livelihood Article 39(a); and equal 
pay for equal work for both men and women Article 39(d).To promote justice, on a basis of equal opportunity and to provide free legal aid by suitable legislation or scheme or in any other way to ensure that opportunities for securing justice are not denied to any citizen by reason of economic or other disabilities (Article 39 A).The State to make provision for securing just and humane conditions of work and for maternity relief (Article 42). The State to promote with special care the educational and economic interests of the weaker sections of the people and to protect them from social injustice and all forms of exploitation (Article 46). The State to raise the level of nutrition and the standard of living of its people (Article 47). Not less than one- third of the total number of offices of Chairpersons in the Panchayats at each level to be reserved for women Article 243 D (4).

In the rural are the rights of women totally violated. The parents are unable to give proper livelihood. Below 18 year girls are violated by the family member. And many time in urban area we saw the without remuneration work that's called beggar. This beggary is totally prohibited by the law. Now a day's human trafficking is very popular specially girls for sexual slavery. It is serious for human freedom and civilization. After trafficking many time trafficker uses for prostitution, pornography and now a day's lots of news spread about sexual abuse.

There are also many rights violated by the family or family member. Child marriage, force to infanticide. Dowry and bride burning, domestic violence, disparity of education etc is a big problem, sexual harassment, deprive from property etc all problems is serious for now a days.

https://goo.gl/fRhym6 Dated 24.07.2018

MARCH FORWARD RAISE AWARNING IN INDIA FOR PROTECT THE WOMEN RIGHTS

There are several steps for awarning the women and child rights and their issues. Various NGO, CVO, Non profit Company, Society and Trust working together and Govt. also working together for protect the rights and violation against women.

Initiative taken by Mother NGO/INGO and world wild organization for protect women rights"-

The UN fund and UNICEF fund urgency established in order to protect women rights and remove the violation. The commissions for women also established for protect the women rights and give them protection for the violence.

\section{Step taken by the Indian Govt. for protect the women rights:-}

Govt. Of India also give some measure for protect women rights. The constitution of India gives several freedom and rights and order to freedom of right. CSWB established for protection of women rights. Govt. of India provides several Acts and amendment the old Acts, for protect women rights, these are follows:-

$>$ The domestic violence Act, 2005

$>$ Dowry prohibition Act, 1961

$>$ Immoral traffic prevention Act, 1956

$>$ Equal remuneration Act, 1976

Maternity benefit Act, 1961

> Sexual harassment Act, 2013

\section{Special initiative for women:-}

Some initiative taken by Govt. and different Ministries, these are follows-

$>$ National commission for women.

$>$ Reservation for women in local self-governance.

$>$ National plan of action for the protection of girl child.

$>$ National policy for the empowerment of women, 2001.

\section{NECESSITY OF AWARENESS}

India is only one place where women are huge amount population. They are the future they build the future of the country. So we have to protect rights of women. Fundamental right is protected by constitution. So at first have require the education cause without education they cannot make them comparable among the society. Society has to protect from the sexual harassment and trafficking. If parents and society not give those rights and freedom they will be deprived. So there very much awareness need created for protection of women rights. The society family as well as society have to aware the fact of the law and they should not influenced by other. They should be aware of bad effect of violence and punishment under Act. Awareness should be made for compulsion of education. In rural India many families are not aware of benefit of education and not give freedom of the child. Many places women are violated but her husband or relative. Dowry death and torture is common factor for women cases. Child marriage destroyed the full life of girl child and deprived them. All cases are punishment is not main 
fact only awareness fact is important. It to be understands to all parents and society member girls and women have full life freedom and no one can seize it. No one have any authority to seize or forced to. Next is child labour, child can understand the responsibility of work, so parents never to be force to work hard or slavery this awarning is important. Parents have to know that punishment is not a true solution for the girl child or women.

Few steps for providing awareness:-

Awareness camp organized for awarning purpose of the community.

$>$ Govt. should provide special scheme and policy for protect women rights.
Monitoring programme is important for child marriage, child labour, domestic violence, trafficking etc.

Panchayt and municipality and school teacher should aware of the policy.

\section{CONCLUSION}

Women are the future of our society, if we are not provide the rights freedom and decision making role that's the reason for women abuse, violation and they can't became proper member of society. All's have full rights to live stay in freedom and peace in safe and protected environment. So there should be enough steps taken for safety and protection of rights.

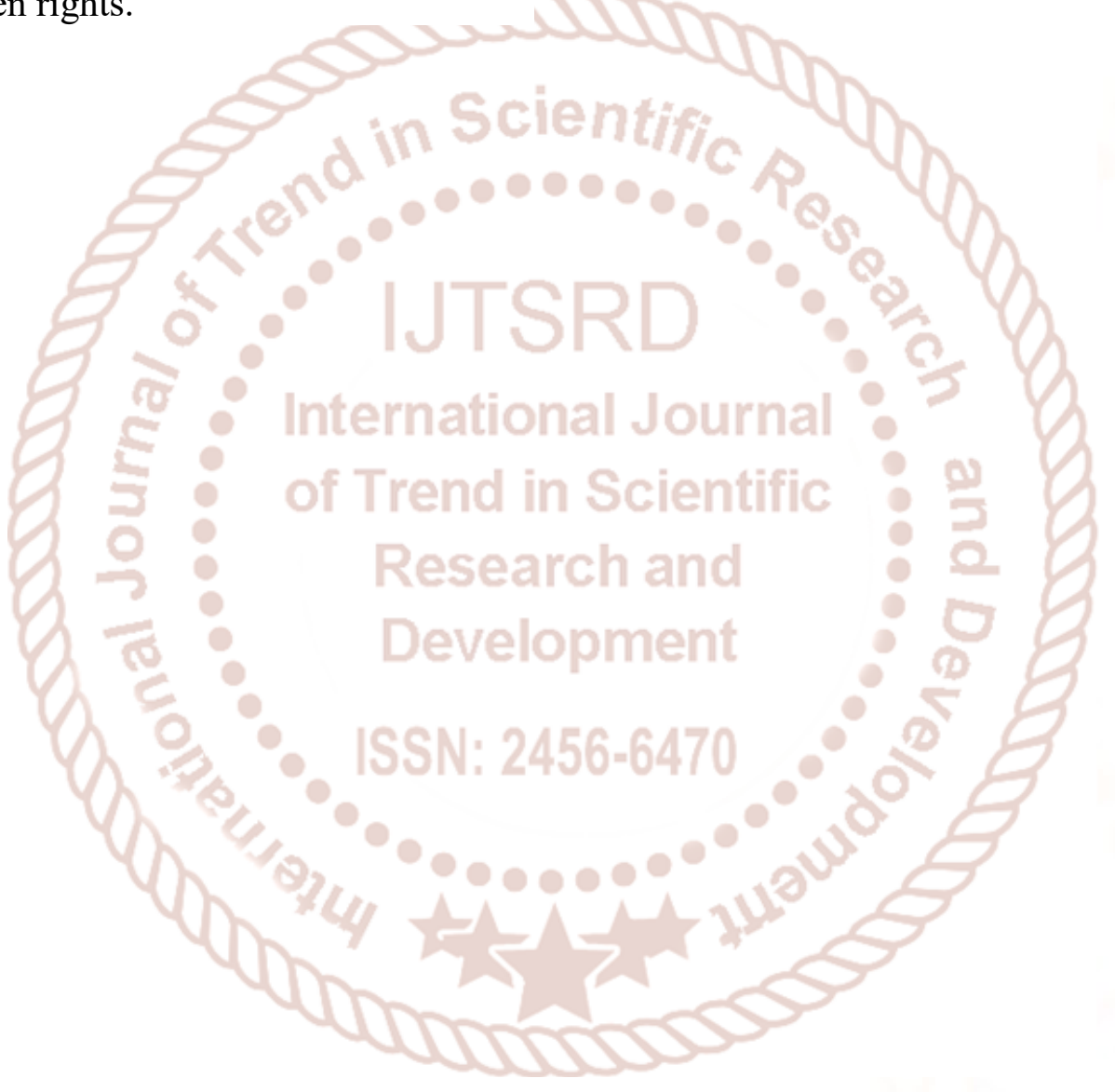

